\title{
Miranda
}

Revue pluridisciplinaire du monde anglophone /

Multidisciplinary peer-reviewed journal on the English-

speaking world

$8 \mid 2013$

In Umbra Voluptatis : Shades, Shadows, and their

Felicities / Film Adaptations, New Interactions

\section{James Kennaway, Bad Vibrations. The History of the Idea of Music as a Cause of Disease}

\section{Nathalie Vincent-Arnaud}

\section{(2) OpenEdition}

\section{Journals}

\section{Electronic version}

URL: http://journals.openedition.org/miranda/3381

DOI: 10.4000/miranda.3381

ISSN: 2108-6559

\section{Publisher}

Université Toulouse - Jean Jaurès

\section{Electronic reference}

Nathalie Vincent-Arnaud, "James Kennaway, Bad Vibrations. The History of the Idea of Music as a Cause of Disease", Miranda [Online], 8 | 2013, Online since 28 June 2013, connection on 16 February 2021. URL: http://journals.openedition.org/miranda/3381 ; DOI: https://doi.org/10.4000/miranda.3381

This text was automatically generated on 16 February 2021.

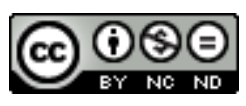

Miranda is licensed under a Creative Commons Attribution-NonCommercial-NoDerivatives 4.0 International License. 


\title{
James Kennaway, Bad Vibrations. The History of the Idea of Music as a Cause of Disease
}

\author{
Nathalie Vincent-Arnaud
}

\section{REFERENCES}

James Kennaway, Bad Vibrations: The History of the Idea of Music as a Cause of Disease

(Farnham: Ashgate, 2012), 213 p, ISBN 978-1-4094-2642-4

1 The tell-tale front cover of the book is unsurprisingly illustrated by a famous caricature of Wagner-held responsible for a variety of music-induced troubles, as is shown further on-by celebrated nineteenth-century French artist André Gill. The picture itself, and the way it is used as a frontispiece, both call to mind the detail from The Garden of Earthly Delights by Hieronymus Bosch which has been chosen to introduce La Mélophobie littéraire (Frédéric Sounac, dir., La Mélophobie littéraire. Littératures, 66 [Toulouse: Presses Universitaires du Mirail, 2012]), a volume published some two months after James Kennaway's work ${ }^{1}$. This closeness in time and in visual presentation testifies to the current relevance of the overall subject addressed by the two books: the various representations of music as an object of distrust, if not distaste, as something that must be held at bay somehow because of its potential dangers, these being "forever allegorized by the Sirens of the Odyssey" (Sounac, La Mélophobie littéraire, 101; my translation), an episode recalled by James Kennaway himself (53).

Music as a source of pleasure and "positive" emotions or efficiently making up for the inadequacy of language, capturing something of the cosmic harmony is now, if not a hackneyed, at least a well-known subject. Swerving from the shakespearian flourish based on the idea of music as "a regimen for the body and soul" (31), the links that bind together music and pathological phenomena have been increasingly explored in the past few years. The issue has been tackled from different angles, one of them being, of 
course, the intricacies of the musician's creative impulse and so-called "madness" (Thomas Dommange, L'Homme musical. La notation en mots dans l'œuvre de Schumann [Besançon: Les Solitaires Intempestifs, 2010]; John T. Hamilton Music, Madness and the Unworking of Language [New York: Columbia University Press, 2008]) while another one concerns more specifically the effects produced on the listener. These "negative" sides of music and, occasionally, the "meloscepticism" (Timothée Picard, "Le méloscepticisme des penseurs et écrivains européens : proposition de typologie", in Claude Coste, Bertrand Vibert, dir., La Haine de la musique. Recherches et Travaux $\mathrm{n}^{\circ} 78$ [Grenoble: ELLUG, 2011], 13-35, 13) that they may trigger off have appeared as a new source of interest among researchers. In the wake of Pascal Quignard's La Haine de la musique (1996), this now regularly refuelled academic concern has given birth to collective investigations, as proved by such titles as La Haine de la musique (2011), a volume of scholarly essays named after Quignard's eponymous work, and, of course, the newly-published La Mélophobie littéraire, mentioned above. As both titles suggest, the two works concentrate on the literary portrayals of music as a threat to the individual, if not as a kind of public enemy when it is, for instance, used as "easylistening", paradoxically dis-enchanting the world (Nathalie Vincent-Arnaud, "The No Music City? La musique comme non-lieu chez Bret Easton Ellis", in Sounac, dir., La Mélophobie littéraire, 185-193, 193), annihilating "convictions, passions, involvements, rebellions" (Claude Chastagner, "Easy-listening : l'indifférence du plaisir", in Le Plaisir, Nathalie Jaëck, Hervé Fourtina et Joël Richard, dir. [Bordeaux: Presses Universitaires de Bordeaux, 2006], 211-19, 218; my translation)-though of course, this is but one facet of a complex issue which also encompasses the various aspects of what has been aptly termed "music of cruelty" (Stéphane Malfettes, Les Mots distordus. Ce que les musiques actuelles font de la littérature [Paris: Éditions Mélanie Séteun, 2000], 94, my translation) which may also be examined outside the specific field of literature.

3 Accordingly, James Kennaway's book brings together, on the whole, literary and sociological concerns and is, therefore, aimed at various categories of readers who are likely to find, first and foremost, a large amount of scholarly documentation in this book. The author, historian of medicine at Durham University, is known for his interest and specialization in music as an aesthetic, bodily experience and in its consequences on human health and balance. His current research project being "Pathological Sounds: the History of Music as a Threat to the Nerves" ${ }^{2}$, this book comes as no surprise in the context of his academic achievements. Published in the Ashgate series "The History of Medicine in Context", it marks a definite stage in the history of music, displaying an innovative and wide-angled vision of what is at stake in showing music as offensive and detrimental to health, or even in making it so.

4 Out of the 213 pages of the book, no fewer than 48 are devoted to a rich and extensive bibliography, a number that might appear at first sight as verging on the inordinate if it were not entirely justified by the author's "interdisciplinary approach" which he describes as "an engagement with a wide range of subjects", among which "neurology and physiology of music, psychiatry, music criticism, musical aesthetics, gender studies, the history of the body and the history of emotions" (17). The bibliographical outcome of this quest for cross-fertilizing fields encompasses references to such varied material as medical or musical reviews, historical, philosophical or literary essays, while the 5-page index mixes names of composers, philosophers, writers with musical genres, historical facts and a number of supposedly music-induced pathological troubles. Even though finding one's way through such a plentiful bibliography may be a 
little challenging in the absence of clearcut thematic sections, the index fully plays its part by providing a convincing bird's eye view of the main areas brought into relief: indeed, it gives definite prominence to "degeneration", "hysteria", "nazis", "nervousness", "nervous system", "neurasthenia", "racism", the name of "Wagner" being also-as a reminder of the front cover-one of the most substantial entries. Some of these are pervaded with echoes of such an emblematic work as Thomas Mann's Magic Mountain which shows musical rapture experienced in the context of a fin-de-siècle malaise that, despite its very name, seems to know no temporal limits.

The volume is divided into five parts which, on the whole, follow a chronological order -from Antiquity to nowadays-, laying emphasis on the varying modes of use and reception of music through time, although many thematic cross-references are made by the author. On a general plane, the ability of music to foster distraction, violence and (self-)destruction is brought to the fore from the very beginning, exemplified by some of the first well-known "victims" of this power, King Erik I of Denmark and Alexander the Great (1-2). The variety of situations mentioned within a few lines, along with the historical and philosophical paths (from Plato to Leibniz and Foucault) explored in this first chapter, adumbrate the far-reaching prospect of the book, along with the timeless relevance of many of the troubles investigated: in this perspective, crime-inducing music can be seen as the link that binds together the story of Erik I of Denmark and the ravings-or actual deeds?-of Bret Easton Ellis's fictional hero Patrick Bateman in American Psycho, both of them sharing the "experience of becoming other" (Hamilton, 32). If this otherness often takes less extreme forms, it is, however, closely connected with the process of "enslaving" underscored by Quignard (Sounac, La Mélophobie littéraire, 11; Vachaud, in Coste and Vibert, La Haine de la musique, 43) and by the advocates of "meloscepticism". Some of the black and white drawings and photographs inserted in the first half of the volume testify to this alienation, the closeup of the music fan at a live concert being particularly significant.

6 The structure of the book provides the reader with easy access to the key historical stages in the vision of music and in the way, far from being appraised as it should be, it sometimes turns out to be a mere tool in the service of a certain moral policy: "For those who opposed the excesses of the cult of feeling, the idea of music as a potentially dangerous stimulant was a useful weapon" (53). The nineteenth century is particularly fraught with such considerations, concentrating for instance on the "hypersthenic" effects that music has on-victims of its tentalizing power just as they were said to fall prey to the diabolus in musica during the Middle Ages-and holding Wagner's hypnotic music responsible for mental disturbances that include the undermining of "the willpower and the masculinity of nervous male listeners ..., leaving them vulnerable to the pathological condition of homosexuality" (87). The Nazi policy is, of course, later brought to the fore as an instance of public hatred for certain "degenerate" kinds of music, such as jazz, whose sensual appeal strays far from the orderly rhythms of military anthems and from the idea of a disciplined self. Here again, the iconographic material-the poster for the 1938 Nazi "Degenerate Music" exhibition-is very useful.

7 As a consequence of the overall chronological order, the final part of the book lingers on some of the latest developments in the conception of music. Whereas the moralizing bias is still at work in the last decades of the twentieth century with the stigmatization of rock music and heavy metal as harbouring "satanic" forces and being a "threat to the social statu quo" (Malfettes, Les Mots distordus, 17; my translation), the "pathogenic" 
reality of music is brought to light with reference to torture. While "the spectre of the Bach-loving war criminal" (147) is conjured up-simultaneously calling to the reader's mind the figure of Hannibal Lecter in The Silence of the Lambs-, the essay investigates the new dimension of "pathological music", involving both "sexually explicit songs" and "sensory overload" (151) to defeat the prisoners in such places as Guantanamo Bay or Abu Ghraib. This is where utter diversion of music from its original aim-a loss of control equated with pleasure and relief-reaches a frightening, hateful climax.

Prolific, richly-documented, James Kennaway's book is equally enjoyable in tone and style, and the author's humanistic concerns make it particularly lively and convincing throughout, teeming only with the good vibrations of knowledge and scientific enthusiasm.

\section{NOTES}

1. The front cover of La Mélophobie littéraire may be seen via the following link: http://w3.pum.univ-tlse2.fr/ no-66-La-melophobie-litteraire .html\#

2. A detailed description of this project may be found via the following link: http://www.dur.ac.uk/chmd/research/pathologicalsounds/

\section{INDEX}

Mots-clés: mélophobie, méloscepticisme, musique, pathologie

Keywords: melophobia, meloscepticism, music, pathology

\section{AUTHORS}

\section{NATHALIE VINCENT-ARNAUD}

Université de Toulouse-Le Mirail

Professeur des universités

nathalie.vincentarnaud@sfr.fr 